\title{
Evaluation of Chemical and Physical Profiles of Three Cacao Areas Located in an Inceptisol from El Carmen, Manabí Province, Ecuador
}

\author{
${ }^{1}$ University of Sancti Spíritus, Cuba \\ ${ }^{2}$ Universidad Tecnológica Equinoccial Santo Domingo campus, Ecuador \\ ${ }^{3}$ Martha Abreu University of Las Villas, Cuba \\ ${ }^{4}$ Universidad Tecnológica Equinoccial Santo Domingo campus, Ecuador
}

Alfredo Reyes Hernández*1, Amstrong Edison Agustín Vera Loor² and Ariany Colás Sánchez ${ }^{3}$

Received: June 16, 2018; Published: June 21, 2018

*Corresponding author: Alfredo Reyes Hernández, University of Sancti Spíritus, Cuba, Email: alfredo@uniss.edu.cu

\begin{abstract}
Summary
The work was developed in areas of production of cocoa crops in an Inceptisol of the canton El Carmen, Manabí province, Ecuador in the months of November and December 2016 at altitude $300 \mathrm{~m}$ asl, latitude 0 16'11 "South, length: 79o 43 '33' 'W and precipitation of $2700 \mathrm{~mm}$ on average annually with the objective of evaluating chemical and physical properties of profiles representative of an Inceptisol dedicated to the production of cocoa of different established ages. The research was exploratory where they made soil profiles in cocoa plantations with 2, 6 and 10 years, where three samples were taken from each horizon of $1 \mathrm{~kg}$. Each replica was determined in $\mathrm{pH}\left(\mathrm{H}_{2} \mathrm{O}\right)$ and in $(\mathrm{KCl})$, organic

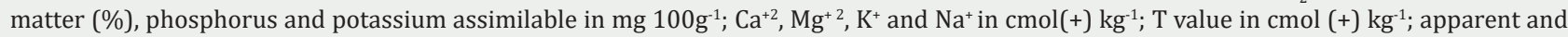
real densities in $\mathrm{g} / \mathrm{cm}^{3}$. Descriptive statistical analyzes, bilateral Pearson correlations and simple regression were performed. It was concluded that: the highest percentage of organic matter was found in the first horizon, while the contents of phosphorus and potassium assimilable were low, with predominance of calcium within the bases changeable; the total porosity of the soil was the one with the most standard deviation and variation with respect to the rest of the properties studied and the percentages of organic matter showed a positive relationship with the apparent density of the soil, but magnesium had a negative impact on the available potassium.
\end{abstract}

Keywords: Physical properties; Organic matter; Soil fertility; Soil acidity

\begin{abstract}
The present research was carried out in cocoa production areas belonging to an Inceptisol from El Carmen canton, which is located in Ecuador, specifically in Manabí province. It was developed from November through December 2016 at 300m above the sea level, at a latitude of $0^{\circ} 16^{\prime} 11^{\prime \prime} \mathrm{S}$, a longitude of 79 $43^{\prime} 33^{\prime \prime} \mathrm{W}$ and an average annual precipitation of $2,700 \mathrm{~mm}$. The study was aimed at evaluating chemical and physical properties of the representative profiles of an Inceptisol devoted to the production of cocoa developed in different periods. In this exploratory research soil profiles were carried out in cocoa plantations having 2, 6 and 10 years, from which three samples of each horizon of 1 $\mathrm{kg}$ were taken. Each sample was analyzed according to the following features: $\mathrm{pH}$ in $\mathrm{H} 2 \mathrm{O}$ and $\mathrm{KCl}$, organic matter (\%), assimilable phosphorus and potassium measured in $\mathrm{mg} 100 \mathrm{~g}^{-1}, \mathrm{Ca}^{+2}, \mathrm{Mg}^{+2}, \mathrm{~K}^{+}$and $\mathrm{Na}^{+}$in $\mathrm{cmol}(+) \mathrm{kg}^{-1}, \mathrm{~T}$ Value in $\mathrm{cmol}(+) \mathrm{kg}^{-1}$, as well as bulk and weight density in $\mathrm{g} /$ $\mathrm{cm}^{3}$. Descriptive, Pearson product-moment correlation and simple regression analyses were conducted. It was concluded that the highest organic matter percentage was found in the first horizon, whereas assimilable phosphorus and potassium levels were low with calcium being predominant within the exchangeable cations. The soil total porosity showed the highest typical deviation and variation taking into account the rest of the properties that were studied. Organic matter percentages showed a positive relationship with the soil bulk density, notwithstanding, magnesium had a negative effect on the available potassium.
\end{abstract}

\section{Introduction}

In Ecuador it is important to adopt agricultural techniques aimed at strengthening the cocoa sector, based on the management and conservation of soils, in order to improve the productivity of cocoa

and raise the socio-economic level of life of farmers who are engaged in this Type of crop. The cultivation of cocoa is very important for the economy of the country, since at the moment it represents 
the third item in agricultural exports and constitutes the source of income for more than 500,000 families [1]. Ecuadorian Creole cacao has been listed as one of the best in the world for its aroma and is a very important crop in the agricultural economy. Ecuador at the world level is the number seven producer of cocoa, by 2012 it had an area of 521091 hectares, a little over 100000 families are distributed in the area planted with cocoa, with an average area of 5.21 ha, but in total a little more than 500000 families depend on this agricultural sector and has exported 221793 t, of which 70\% was of the fine Criollo variety of considerable aroma. Sales left an income of 425790,442 USD, which is why it is necessary to carry out scientific studies that allow better management and care of the soil as the main basis for the sustainability of the agricultural economy and food for our peoples [2].

Agriculture in Ecuador has developed more and more rapidly, making more intensive the use of fertilizers and other chemical inputs, where agricultural practices that have led to soil erosion (irreversible effect), loss of fertility, pollution of groundwater, depletion of soils, environmental pollution and low quality food. The importance of evolution in soil degradation is that it can be reversible in the long term, such as the decline of organic matter, or is irreversible as erosion, so the agricultural sector requires balancing three aspects of the quality of the soil. floor:

\section{a) Fertility}

b) Environmental quality

c) The protection of wildlife and human health [3].

The primary macro nutrients are those that are extracted in greater quantity and that for diverse reasons, it is necessary to recover habitually, if it would not reduce the fertile and productive capacity of the soils and the productive level of the crops would decrease $[4,5]$. Fertilization is an indispensable agricultural resource to increase production. The cultivation of cocoa may require some nutrient that is limiting its normal development and production. The amount or dose of fertilizers is variable and depends on the type of soil, the chemical and physical properties of the soil, the climate, the shade tree and the state of development of the plant. The need to maintain the balance between nutrients in the soil requires applications of $\mathrm{N}, \mathrm{P}$ and $\mathrm{K}$ and other nutrients depending on the amount that exists in the soil.

The removal of nutrients by the cocoa crop increases rapidly during the first 5 years after sowing and then it is maintained with the same absorption rate for the rest of its useful life [6]. In agriculture the production of a crop can be measured by the dose of each element applied. When there is a management of fertilization with predetermined specific doses, the variability of each element can be measured and managed to increase the productive efficiency of the crop and the farmer can have a better economic sustenance, in which he would support his decisions for the management of his crop [7]. The author adds that in investigations carried out the extraction of nutrients that the cocoa crop performs for every 1000 $\mathrm{kg}$ of dry almonds is 30; 8 and $40 \mathrm{~kg}$ of N, P2O5 and K2O; therefore, the quantities that should be in the fertilization program should consider this extraction, regardless of the characteristics of the soil where the plants are located. In some areas the Inceptisols are soils with a minimum profile development (more developed than the Entisols), while in others they are soils with diagnostic horizons that do not meet the requirements for other soil orders, they can present diagnostic horizons and epipediones as the Umbrian, Anthropic, Ocheric, Histic, Mollic and Plaggen. But only a few have a mollic epipedion and the most common diagnostic horizons are the Cambrian horizon and a fragipan, although calcic, petrocalcic or duripan horizons may also appear [8].

These soils have a very slow surface runoff and can have a very high water table in winter, which decreases as moisture stops [9]. They should be interpreted as immature soils that have a weak morphological expression of mature soils. They show altered horizons that have suffered loss of bases, iron and aluminum, but retain considerable reserves of weatherable minerals. Primary or secondary minerals are present, also appearing in alluvial, colluvial sediments. The influence of vegetation on the Inceptisols is reflected by their representation in forest ecosystems, agricultural lands and meadows, being the forest areas where they are most frequently [8]. The primary and secondary minerals are present in these soils, appearing also in young geological sediments (alluvial, colluvial, loess). The material that is highly calcareous and resistant to weathering inhibits the development of the soil and therefore favors the development of the Inceptisols. Decomposition, humification and mineralization of waste favor the accumulation of organic matter, as well as processes of carbonation and decarbonation, with the possible formation of calcic horizons [10]. In the canton El Carmen, the $\mathrm{pH}$ that predominates in the territory is that which is in the range of 4.5 to 5.5; considering these soils as acids, possibly due to the fact that as El Carmen is a rainy zone due to the dissolution effect, the bases are percolated ( $\mathrm{K}, \mathrm{Ca}, \mathrm{Mg}$ and other cations), or leached in considerable proportions.

Another cause of these soils being acidic is crops that, when not fertilized, cause the plants to absorb the soil bases and increase the concentration of hydrogen ions, which produces the acidity of the soil. $73.23 \%$ of the surface of the soil of the canton of El Carmen is acid, being an important limitation when using these soils for agricultural activity since it influences: assimilation of the micro elements and macro elements, fertility of the soils, in the life of the micro flora and micro fauna. These soils are distributed mostly to the north and east of the canton. Based on what is observed in the field and the various conversations with producers in the area, they mention that crop yields have decreased and continue to decrease, owing among other causes to the level of acidification that has increased, due to several factors: $\nabla$ Loss of the arable layer due to erosion, since the producers keep the soil free of plant cover and, with the rains, the fine particles of the soil are lost, decreasing their fertility.

Extraction of nutrients in intensive farming systems, without the contribution of nutrients in an organic or chemical way. Residual acid effect of ammoniacal nitrogen fertilizers, such as the application of urea that is carried out without a technical support and often 
in doses higher than those needed by plants. $\bigotimes$ Inadequate handling of liming, mainly in crops that are not technified where they use products that are not suitable for increasing soil $\mathrm{pH} \otimes$ Little use of techniques to diagnose soil fertility, most producers do not perform physical, chemical and biological soil analysis, which allows to know the deficiencies and correct them to improve crop production. By way of summary, it can be said that there are a number of difficulties related to cocoa production in the canton of El Carmen, province of Manabí, among which are:

a) A low average yield, which fluctuates between 0.23 and 0.77 tha-1 year-1.

b) There are 100961 hectares planted with cocoa and 52 546 of them are monocultures and 48415 with other associated crops.

c) Lack of linking of practical knowledge with scientists.

d) Low soil fertility for cocoa production, mainly acid $\mathrm{pH}$.

e) Continuous use of chemical fertilizers at a rate of 50, 23 and $100 \mathrm{~kg}$ of $\mathrm{N}_{2} \mathrm{P}_{2} \mathrm{O}_{5}$ and $\mathrm{K}_{2} \mathrm{O}$, respectively.

For the above reasons, the objective of the research was to evaluate chemical and physical properties of representative profiles of an Inceptisol dedicated to the production of cocoa of different established ages.

\section{Materials and Methods}

The type of research was exploratory for which soil profiles will be made in the areas with cocoa plantations with 2, 6 and 10 years. Soil samples will be taken from each layer or horizon of each profile, delimited by changes in coloration, always starting with the lower ones to avoid contamination of the samples and in quantities of $1.5 \mathrm{~kg}$ each according to the methodology of [11]. The chemical and physical and chemical properties that were evaluated to each of the samples of the horizons by profiles were the following: $\mathrm{pH}$ in $(\mathrm{H} 20)$ and in $(\mathrm{KCl})$ by potentiometric method soil-solution ratio 1 : 2.5; organic matter (\%) by Wakley - Black method, colorimetry and oxidation with $1 \mathrm{~N}$ potassium dichromate and concentrated sulfu- ric acid; phosphorus and potassium assimilable in mg $100 \mathrm{~g}-1$ by Colorimetry and flame photometry, respectively, using extraction with $0.1 \mathrm{~N}$ sulfuric acid, soil-solution ratio 1: 2.5 ; for 3 minutes; $\mathrm{Ca}^{+2}, \mathrm{Mg}^{+2}, \mathrm{~K}+$ and $\mathrm{Na}^{+}$in $\mathrm{cmol}(+) \mathrm{kg}^{-1}$ with extractive solution $\mathrm{NH} 4$ $\left(\mathrm{CH}_{3} \mathrm{COO}\right) 1 \mathrm{~N}$ of $\mathrm{pH}=7$ where $\mathrm{Ca}$ and $\mathrm{Mg}$ were by EDTA titration whereas $\mathrm{K}$ and $\mathrm{Na}$ by flame photometry; $\mathrm{T}$ value in $\mathrm{cmol}(+) \mathrm{kg}^{-1}$ by a solution of ammonium acetate $\mathrm{NH} 4\left(\mathrm{C}_{2} \mathrm{H}_{3} \mathrm{O}\right)$, Schaschtschabel method; apparent densities by the cylinder method and real density in $\mathrm{g} / \mathrm{cm}^{3}$ by the pyknometer method; value $\mathrm{V}$ and total porosity by calculation expressed in (\%); according to the [12]. Analyzes were carried out: descriptive statistics, bilateral Pearson correlations and simple regression with the IBM statistical processors. SPSS. Stactistics (Version 21.0 on Windows) and STAHTGRAPHICS Centurion Version 15.2 on Windows.

\section{Results and Discussion}

The $\mathrm{pH}$ values in both water and $\mathrm{KCl}$, regardless of the age of the cocoa plantations, fall within the evaluation categories from mildly acidic to slightly acidic, with the tendency to become more acidic as the depths are increased. soil profiles (Table 1). In the case of the percentages of organic matter it was possible to appreciate that their greater quantity always is in the superficial horizons, own of the process of accumulation of leaf litter of the own crop, fundamentally in the plantations of greater time of established. It is emphasized that in the case of the profile located in the plantation of only two years, the percentages of 4.69 of the first $14 \mathrm{~cm}$ and 2.34 in the next $10 \mathrm{~cm}$ are related to the cultural precedent that existed before the establishment of the Cocoa growing. But this indicator 10 years after the establishment of the plantation, the tendency is towards a greater accumulation in the first two layers of the soil, a very positive aspect for the sustainability of the system. The results found with respect to the $\mathrm{pH}$ values and the percentage of organic matter corroborate what was stated by [10]. when expressing that decomposition, humification and mineralization of the waste, which favor the accumulation, can occur for the type of soil under study. of organic matter, as well as processes of carbonation and decarbonation, with the possible formation of calcic horizons.

Table 1: Chemical properties for depths of the soil profile of cocoa plantations of 2, 6 and 10 years established.

\begin{tabular}{|c|c|c|c|c|c|c|}
\hline Cocoa plantation & Depth pH & (water) pH & $\begin{array}{c}\mathrm{pH} \\
(\mathrm{KCl})\end{array}$ & M.O. (\%) & $\begin{array}{c}\text { P205 } \\
\text { (mg.100 g-1) }\end{array}$ & $\begin{array}{c}\text { K20 } \\
\text { (mg.100 g-1) }\end{array}$ \\
\hline \multirow{6}{*}{2 years } & $0-14 \mathrm{~cm}$ & 5,83 & 5,14 & 4,69 & 5,70 & 0,68 \\
\hline & $14-24 \mathrm{~cm}$ & 5,80 & 5,15 & 2,34 & 3,97 & 1,58 \\
\hline & $24-36 \mathrm{~cm}$ & 5,95 & 5,07 & 1,36 & 3,35 & 2,29 \\
\hline & $36-74 \mathrm{~cm}$ & 5,86 & 4,93 & 1,60 & 2,87 & 1,20 \\
\hline & $74-90 \mathrm{~cm}$ & 5,63 & 4,63 & 1,48 & 1,61 & 0,41 \\
\hline & $90-120 \mathrm{~cm}$ & 5,83 & 4,76 & 0,74 & 1,17 & 0,29 \\
\hline \multirow{6}{*}{6 years } & $0-10 \mathrm{~cm}$ & 5,85 & 5,01 & 3,63 & 4,48 & 0,68 \\
\hline & $10-23 \mathrm{~cm}$ & 6,23 & 5,06 & 1,67 & 3,13 & 1,58 \\
\hline & $23-61 \mathrm{~cm}$ & 6,03 & 5,14 & 1,60 & 4,91 & 2,29 \\
\hline & $61-92,5 \mathrm{~cm}$ & 5,84 & 5,08 & 1,34 & 4,53 & 1,20 \\
\hline & $92,5-113 \mathrm{~cm}$ & 6,19 & 4,91 & 0,81 & 3,59 & 0,41 \\
\hline & $113-120 \mathrm{~cm}$ & 6,15 & 4,86 & 0,86 & 2,83 & 0,29 \\
\hline
\end{tabular}




\begin{tabular}{|c|c|c|c|c|c|c|}
\hline \multirow{5}{*}{10 years } & $0-10 \mathrm{~cm}$ & 5,85 & 5,01 & 5,10 & 29,09 & 0,99 \\
\cline { 2 - 7 } & $10-19 \mathrm{~cm}$ & 6,23 & 5,06 & 3,28 & 20,02 & 1,25 \\
\cline { 2 - 7 } & $19-41 \mathrm{~cm}$ & 6,03 & 5,14 & 1,85 & 16,31 & 2,13 \\
\cline { 2 - 7 } & $41-77 \mathrm{~cm}$ & 5,84 & 5,08 & 1,68 & 6,61 & 2,63 \\
\cline { 2 - 7 } & $77-111 \mathrm{~cm}$ & 6,19 & 4,91 & 0,98 & 6,61 & 0,34 \\
\cline { 2 - 7 } & $111-120 \mathrm{~cm}$ & 6,15 & 4,86 & 0,74 & 6,60 \\
\hline
\end{tabular}

Source: self made

It is also appreciated that the content of assimilable phosphorus is high and much more in the cocoa area of 10 years, while the assimilable potassium is very low in all layers or horizons, regardless of the time of established cocoa plantations. The low content of potassium expressed in mg.100 g- 1 corroborates what is stated in $[4,5]$ when expressing that the primary macro nutrients are those that are extracted in greater quantity and that they have to be replaced usually, to avoid the detriment of the fertile capacity of the soil in study to avoid that the productive level of the crops, specifically the cocoa, declines. Cation exchange capacity is evaluated as low in almost all layers of profiles made in cocoa plantations, except in those where this value exceeds $20 \mathrm{cmol}(+) . \mathrm{Kg}^{-1}$ of soil where if these become medium values (Table 2). In this sense, Espinosa (2000) has pronounced on the need to develop research in which the extraction of nutrients that the cocoa crop performs for each $1000 \mathrm{~kg}$ of dry almond is considered to be 30; 8 and 40 $\mathrm{kg}$ of $\mathrm{N}, \mathrm{P}_{2} \mathrm{O}_{5}$ and $\mathrm{K}_{2} \mathrm{O}$; because the quantities that should be in the fertilization program should consider this extraction, regardless of the characteristics of the soil where the plants are located. Another aspect to be highlighted in the same table is that of the cations that constitute the degree of saturation of bases ( $\mathrm{S}$ value), the one that predominates is calcium with respect to the rest, sometimes tripling the amount of $\mathrm{Mg}$ in the medium.

Table 2: Cation exchange, base saturation and soil washing by depths of the soil profile of the 2, 6 and 10 year old cocoa plantations.

\begin{tabular}{|c|c|c|c|c|c|c|c|c|}
\hline \multirow[t]{2}{*}{ Cocoa plantation } & \multirow[t]{2}{*}{ Depth pH } & C.I.C & $\mathbf{K}$ & $\mathrm{Ca}$ & Mg & $\mathrm{Na}$ & Value $S$ & \multirow{2}{*}{$\begin{array}{c}\text { Value V } \\
(\%)\end{array}$} \\
\hline & & \multicolumn{6}{|c|}{$\left(\operatorname{cmol}(+) \mathrm{kg}^{-1}\right)$} & \\
\hline \multirow{6}{*}{2 years } & $0-14 \mathrm{~cm}$ & 19,16 & 0,58 & 11,25 & 4,23 & 0,29 & 16,36 & 85,38 \\
\hline & $14-24 \mathrm{~cm}$ & 16,72 & 1,35 & 9,35 & 2,66 & 0,25 & 13,62 & 84,07 \\
\hline & $24-36 \mathrm{~cm}$ & 18,11 & 1,96 & 10,35 & 2,90 & 0,30 & 15,51 & 85,64 \\
\hline & $36-74 \mathrm{~cm}$ & 19,77 & 1,03 & 11,35 & 3,81 & 0,68 & 16,87 & 85,33 \\
\hline & $74-90 \mathrm{~cm}$ & 19,36 & 0,35 & 11,99 & 3,63 & 0,80 & 16,76 & 86,57 \\
\hline & $90-120 \mathrm{~cm}$ & 20,04 & 0,25 & 11,66 & 4,21 & 0,82 & 16,94 & 84,53 \\
\hline \multirow{6}{*}{6 years } & $0-10 \mathrm{~cm}$ & 19,58 & 0,58 & 11,25 & 4,23 & 0,29 & 16,36 & 83,55 \\
\hline & $10-23 \mathrm{~cm}$ & 17,36 & 1,35 & 9,35 & 2,66 & 0,25 & 13,62 & 78,45 \\
\hline & $23-61 \mathrm{~cm}$ & 18,73 & 1,96 & 10,35 & 2,90 & 0,30 & 15,51 & 82,80 \\
\hline & $61-92,5 \mathrm{~cm}$ & 19,23 & 1,03 & 11,35 & 3,81 & 0,68 & 16,87 & 87,72 \\
\hline & $92,5-113 \mathrm{~cm}$ & 17,87 & 0,35 & 11,99 & 3,63 & 0,80 & 16,76 & 93,78 \\
\hline & $113-120 \mathrm{~cm}$ & 21,19 & 0,25 & 11,66 & 4,21 & 0,82 & 16,94 & 79,94 \\
\hline \multirow{6}{*}{10 years } & $0-10 \mathrm{~cm}$ & 21,94 & 0,85 & 13,23 & 3,51 & 0,25 & 17,84 & 81,31 \\
\hline & $10-19 \mathrm{~cm}$ & 18,23 & 1,07 & 11,23 & 2,88 & 0,25 & 15,43 & 84,64 \\
\hline & $19-41 \mathrm{~cm}$ & 17,84 & 1,82 & 10,44 & 2,90 & 0,29 & 15,44 & 86,54 \\
\hline & $41-77 \mathrm{~cm}$ & 21,90 & 2,25 & 12,84 & 3,20 & 0,31 & 18,60 & 84,93 \\
\hline & $77-111 \mathrm{~cm}$ & 20,09 & 1,15 & 12,28 & 3,23 & 0,42 & 17,09 & 85,06 \\
\hline & $111-120 \mathrm{~cm}$ & 20,88 & 0,51 & 13,34 & 3,66 & 0,57 & 18,08 & 86,59 \\
\hline
\end{tabular}

\section{Source: self made}

The result corroborates what was proposed by [10] regarding primary and secondary minerals are present in these soils, since the parent material that is highly calcareous and resistant to weathering inhibits the development of the soil and therefore favors the development of the Inceptisols. This allows that the $\mathrm{V}$ values are also high (less washing to be greater than $70 \%$ ), although the potassium contents are low and with the tendency to find less amount of this in the first layer with respect to the second, regardless of the time of established cocoa plantations. The apparent density of the layers or horizons has a tendency to vary greatly with the depth, as well as the real density, expressed both in $\mathrm{g} / \mathrm{cm}^{3}$. This result means that the total porosity of the soil has very sharp changes as well, since these percentages vary a lot, mainly in the first horizons of the cocoa plantations of 6 and 10 years of planted (Table 3). That is why [9] states that these soils have a very slow surface runoff and may have a very high water table in winter, which decreases as moisture stops, which is in correspondence with the result achieved. In this analysis of the chemical and physical properties of all the soil pro- 
files carried out, it can be seen that there are several of them with values of standard deviation and variance greater than unity, such as the percentage of organic matter, the capacity of cation exchange, the calcium within the changeable bases, the $\mathrm{S}$ and $\mathrm{V}$ values, the

Table 3: Physical properties by depths of soil profiles of cocoa plantations of 2, 6 and 10 years established.

\begin{tabular}{|c|c|c|c|c|}
\hline \multirow[t]{2}{*}{ Cocoa plantation } & \multirow[t]{2}{*}{ Depth pH } & Apparent Density & Real density & \multirow{2}{*}{$\begin{array}{c}\begin{array}{c}\text { Porosity } \\
\text { Total }\end{array} \\
(\%)\end{array}$} \\
\hline & & \multicolumn{2}{|c|}{$\left(\mathrm{g} / \mathrm{cm}^{3}\right)$} & \\
\hline \multirow{6}{*}{2 years } & $0-14 \mathrm{~cm}$ & 0,942 & 2,42 & 61,07 \\
\hline & $14-24 \mathrm{~cm}$ & 0,833 & 2,11 & 60,52 \\
\hline & $24-36 \mathrm{~cm}$ & 0,781 & 2,24 & 65,13 \\
\hline & $36-74 \mathrm{~cm}$ & 0,704 & 2,12 & 66,79 \\
\hline & $74-90 \mathrm{~cm}$ & 0,535 & 1,63 & 67,18 \\
\hline & $90-120 \mathrm{~cm}$ & 0,502 & 1,86 & 73,01 \\
\hline \multirow{6}{*}{6 years } & $0-10 \mathrm{~cm}$ & 0,868 & 1,61 & 46,09 \\
\hline & $10-23 \mathrm{~cm}$ & 0,976 & 1,63 & 40,67 \\
\hline & $23-61 \mathrm{~cm}$ & 0,800 & 1,78 & 55,06 \\
\hline & $61-92,5 \mathrm{~cm}$ & 0,700 & 2,14 & 67,29 \\
\hline & $92,5-113 \mathrm{~cm}$ & 0,749 & 1,82 & 58,85 \\
\hline & $113-120 \mathrm{~cm}$ & 0,581 & 1,83 & 68,25 \\
\hline \multirow{6}{*}{10 years } & $0-10 \mathrm{~cm}$ & 0,972 & 2,02 & 51,88 \\
\hline & $10-19 \mathrm{~cm}$ & 0,774 & 2,24 & 65,45 \\
\hline & $19-41 \mathrm{~cm}$ & 0,832 & 2,21 & 62,35 \\
\hline & $41-77 \mathrm{~cm}$ & 0,826 & 2,08 & 60,29 \\
\hline & $77-111 \mathrm{~cm}$ & 0,638 & 1,96 & 67,45 \\
\hline & $111-120 \mathrm{~cm}$ & 0,462 & 1,93 & 76,06 \\
\hline
\end{tabular}

Source: self made

Table 4: Descriptive statistics of the chemical and physical properties of the soil profiles of the cocoa areas of 2, 6 and 10 years.

\begin{tabular}{|c|c|c|c|c|c|c|}
\hline $\begin{array}{l}\text { Chemical and physical prop- } \\
\text { erties }\end{array}$ & $\mathbf{N}$ & Minimum & Maximum & Media & Typical deviation & Variance \\
\hline pH (water) & 18 & 5,63 & 6,23 & 5,9711 & 0,18195 & 0,033 \\
\hline $\mathrm{pH}(\mathrm{KCl})$ & 18 & 4,63 & 5,15 & 4,9889 & 0,14531 & 0,021 \\
\hline Organic material (\%) & 18 & 0,74 & 5,10 & 1,9861 & 1,32519 & 1,756 \\
\hline $\begin{array}{l}\text { Exchange Capacity }(\operatorname{cmol}(+) . \\
\left.\qquad \mathrm{kg}^{-1}\right)\end{array}$ & 18 & 16,72 & 21,94 & 19,3333 & 1,50996 & 2,280 \\
\hline $\mathrm{K}\left(\mathrm{cmol}(+) \cdot \mathrm{kg}^{-1}\right)$ & 18 & 0,25 & 2,25 & 1,0383 & 0,63761 & 0,407 \\
\hline $\mathrm{Ca}\left(\operatorname{cmol}(+) \cdot \mathrm{kg}^{-1}\right)$ & 18 & 9,35 & 13,34 & 11,4033 & 1,14794 & 1,318 \\
\hline $\operatorname{Mg}\left(\operatorname{cmol}(+) \cdot \mathrm{kg}^{-1}\right)$ & 18 & 2,66 & 4,23 & 3,4589 & 0,56014 & 0,314 \\
\hline $\mathrm{Na}\left(\mathrm{cmol}(+) \cdot \mathrm{kg}^{-1}\right)$ & 18 & 0,25 & 0,82 & 0,4650 & 0,23480 & 0,055 \\
\hline $\mathrm{P}_{2} \mathrm{O}_{5}\left(\mathrm{mg} \cdot 100 \mathrm{~g}^{-1}\right)$ & 18 & 1,17 & 29,09 & 7,42 & 7,4365 & 55,302 \\
\hline $\mathrm{K}_{2} \mathrm{O}\left(\mathrm{mg} .100 \mathrm{~g}^{-1}\right)$ & 18 & 0,29 & 2,63 & 1,2133 & 0,74530 & 0,555 \\
\hline Value $S\left(\mathrm{cmol}(+) \cdot \mathrm{kg}^{-1}\right)$ & 18 & 13,62 & 18,60 & 16,3667 & 1,33688 & 1,787 \\
\hline Value V (\%) & 18 & 78,45 & 93,78 & 84,8239 & 3,27418 & 10,720 \\
\hline Apparent density $\left(\mathrm{g} / \mathrm{cm}^{3}\right)$ & 18 & 0,46 & 0,98 & 0,7486 & 0,15548 & 0,024 \\
\hline Real density $\left(\mathrm{g} / \mathrm{cm}^{3}\right)$ & 18 & 1,61 & 2,42 & 1,9794 & 0,23548 & 0,055 \\
\hline Porosity (\%) & 18 & 40,67 & 76,06 & 61,8550 & 8,94904 & 80,085 \\
\hline
\end{tabular}

Source: self made

assimilable phosphorus and finally the total porosity that presented the highest values of both standard deviation and variance, with values of 8.94904 and 80, 085; respectively (Table 4). 
The results obtained with the investigation of the physical properties in conjunction with the chemical in cocoa plantations correspond to what was stated in [2] since this cultivation in sales have left a lot of income, so it is necessary to carry out scientific studies that allow a more adequate management and care of the soil as the main base for the sustainability of the agricultural economy and food for the cocoa-producing peoples. One of the results of the research is the fact that there is a direct and positive relationship between the percentages of organic matter determined to each layer of the soil profiles with the apparent density, since to the extent that the percentages of the former were higher, so were the apparent density values, with a value of $r=0.6953^{* *}$ (Figure 1 ).

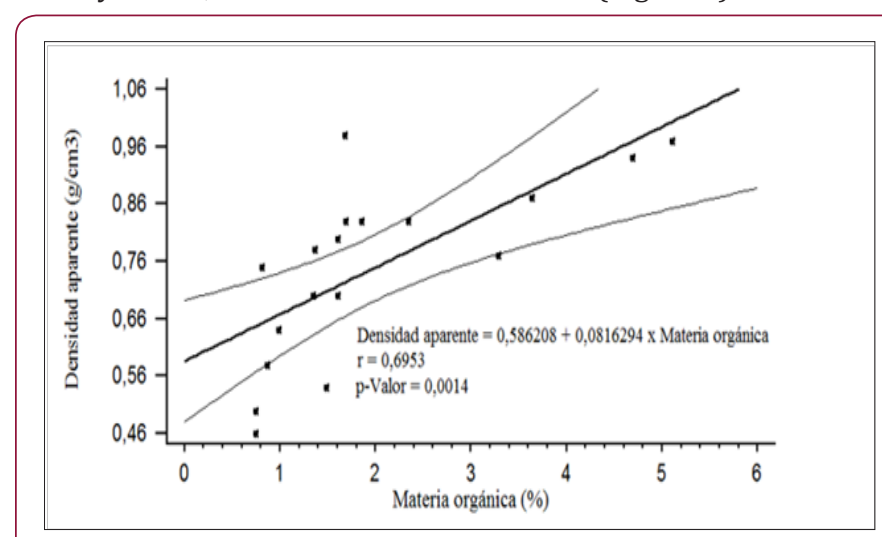

Figure 1: Relationship between the content of organic matter and the apparent density of the soil profiles of the areas of 2, 6 and 10 years.

The amount of magnesium within the degree of saturation of bases determined the availability of existing assimilable potassium since there was a direct but negative relationship between both indicators studied by horizons in the soil profiles, regardless of the time established for the cocoa plantations, when a value of $\mathrm{r}=-0.7534 * *$ (Figure 2). Result that is in correspondence with the raised by [6]. on the need to maintain the balance between nutrients in the soil because this requires applications of $\mathrm{N}, \mathrm{P}$ and $\mathrm{K}$ and other nutrients depending on the amount that exists on the floor. The authors also suggest that the removal of nutrients from the cocoa crop increases rapidly during the first 5 years after sowing and then maintains the same absorption rate for the rest of its useful life.

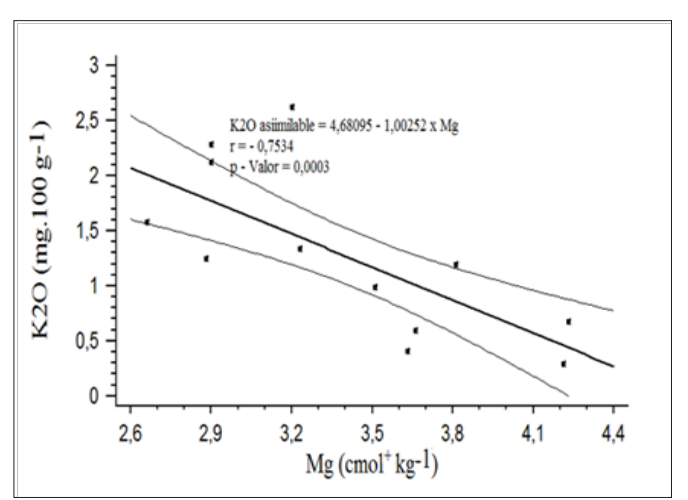

Figure 2: Relationship between the content of organic matter and the apparent density of the soil profiles of the areas of 2, 6 and 10 years.

\section{Conclusion}

a) The highest percentage of organic matter was found in the first horizon, while the contents of phosphorus and potassium assimilable were low, with predominance of calcium within the bases changeable.

b) The total porosity of the soil was the one with the most standard deviation and variation with respect to the rest of the properties studied and the percentages of organic matter showed a positive relationship with the apparent density of the soil, but the magnesium had a negative impact on the available potassium.

\section{References}

1. CORPIE (2010) First international congress with cacao aroma.

2. ANECACAO (2013) National Association of Exporters and Industrialists of Cacao of Ecuador.

3. ICCO (2009) Tropical Agronomic Center for Research and Teaching CATIE. Teaching program for development and conservation. Postgraduate school. Characterization of upper cocoa trees (Theobroma cacao L.). Selected by the genetic improvement program of CATIE, pp. 2-3.

4. EPAG (2000) Practical Encyclopedia of Agriculture and Livestock.

5. INIAP (2011) National Autonomous Institute of Agricultural Research. Characterization of the production systems of the Ecuadorian Amazon final report, Quito, Ecuador, pp. 150.

6. Hadfield W, Vera J (2003) Handbook of the cultivation of cocoa. National Institute of Agricultural Research.

7. Espinosa J (2000) Nutrient management in Agriculture by specific sites in tropical crops, In $11^{\text {th }}$ Fertilizer Latin America International Conference (Cancun Mexico). Memory Cancun. British Sulfur Publishing, P. 13-22.

8. Soil Survey Staff. Keys to Soil Taxonomy, $10^{\text {th }}$ (Edn.) USDA-Natural Resources Conservation Service, Washington DC (2006) Department of Agriculture of the United States, natural resources conservation service. Translation: Ortiz CA; Gutiérrez MC Keys to the soil taxonomy. $\left(10^{\text {th }}\right.$ Edn.).

9. Stolpe N (2006) Descriptions of the main soils of the VIII region of Chile. University of Concepción. Agronomy faculty. Department of Soils and Natural Resources. Chillán, Chile.

10. Gisbert JM, Ibañez S (2010) Genesis of the soil. Editorial Universidad Politécnica de Valencia.

11. Cairo P, Reyes A (2010) Practical Edaphology. Havana: Félix Varela.

12. Methodological Normative Guide (2000) Physical and chemical soil analysis in Edaphological Cartography. National Institute of Statistics and Geography and Information Technology. INEGI. Quito Ecuador. 
(C) (i) This work is licensed under Creative Submission Link: https://biomedres.us/submit-manuscript.php

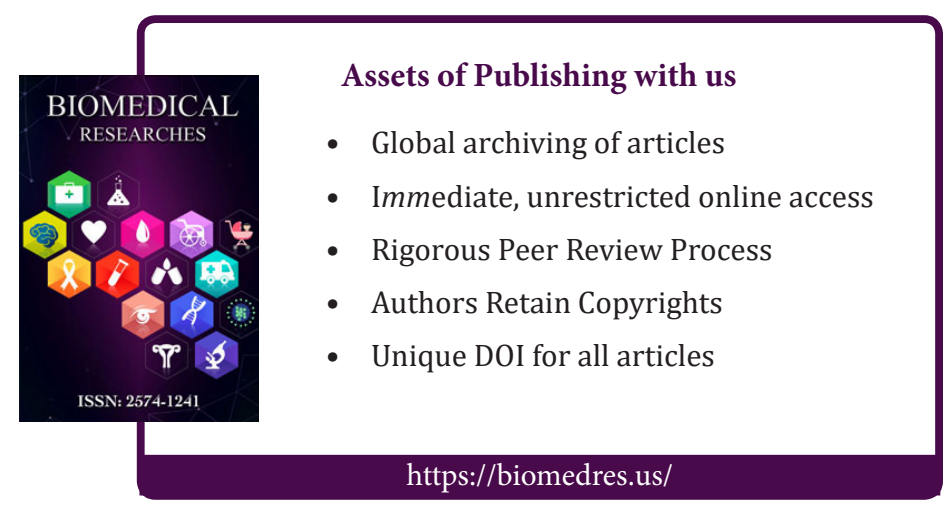

